\title{
BOILER PLANTS AND THE ENVIRONMENT PROTECTION FROM INDUSTRY HARMFUL EFFECTS
}

\author{
${ }^{1}$ Voinov O.P., Doctor of Engineering, Professor, \\ voinova_s@yahoo.com, ORCID: 0000-0001-7548-4212 \\ ${ }^{1}$ Elkin Yu.G., Ph.D., Associate Professor, \\ yrik29@gmail.com, ORCID: 0000-0001-7677-377X \\ ${ }^{1}$ Odessa State Academy of Civil Engineering and Architecture \\ 4, Didrikhson str., Odessa, 65029, Ukraine
}

\begin{abstract}
At present, environmental problems have become aggravated. The production process has a negative impact on the natural environment. It accumulates these harmful secondary effects. The degree of their harmful effects is increasing rapidly. The natural environment, taking into account its self-healing, undergoes dangerous, irreversible changes in its state. Now it is possible to talk only about slowing down this process. The ability to slow down and then stop the increase in the harmful impact on the natural environment is the essence of the nature conservation activities of humanity. It is necessary to move from a strategy of using the natural environment to a strategy of parity interaction with it. The problem was discussed at the Kyoto and Paris conferences of global importance. Among the branches of production, the most dangerous for the natural environment is energy. Its harmful effect is complex. Defending against it is a complex environmental issue. The adopted energy saving program actively contributes to solving the problem of saving the natural environment from degradation and death. The most environmentally aggressive element of power plants is solid fuel boiler plants. Reducing the intensity of their impact is the main direction of activities to protect the natural environment. The most difficult technical object is considered the power unit of a large thermal power plant. The most difficult part is the boiler plant. The most difficult element is the steam boiler. The level of environmental friendliness of the boiler is highly dependent on the degree of its wear. The problem of updating the fleet of boilers is of current importance. The general line of improving the environmental friendliness of production should be considered an increase in the level of environmental friendliness of power plants, especially those using fossil fuels, and a decrease in their emissions of carbon dioxide and heat. It is necessary to improve boiler installations, to increase their efficiency level, and the quality of their management. It is important to ensure the modernization of worn-out boiler installations based on their complete or partial renewal. In the formation of the power engineering of the future, the sociopsychological position of humanity must be radically changed.
\end{abstract}

Keywords: natural environment, world production, energetics, boiler plant, harmful effects, environmental friendliness.

Introduction. The widely established now world production in its development was passing and is passing a rather complex, difficult, but productive path, full of great successes and significant failures, alternating in time and occurring quite often. The development pace of world production is limited by the opposition of existing and especially new large, difficult insurmountable obstacles of various kinds, especially obstacles reaching the level of the problem.

During the industrial and current, stagnant periods of development, world production encountered with the problem of its interaction with the natural environment (NE), which is rapidly becoming more complex. An environmental problem has emerged and is rapidly aggravating in the world [1].

As the experience accumulated by humanity shows, an obligatory effect of the production process passing is its influence on the ambient space, which is the NE. This influence is carried out by a certain residual waste (secondary) product of the ongoing technological process and a certain (secondary) energy affect of this process.

Bulletin of Odessa State Academy of Civil Engineering and Architecture, 2021, no. 85, page 128-136 
These two effects, two inevitable influences on NE are extremely harmful for it, for animate nature and for inanimate nature. At the same time, it is important to note that even partial compensation of these secondary effects is rather complicated and inaccessible.

An important circumstance is the accumulation in the NE the specified secondary effects, harmful to it and the results of production process, which inevitably and continuously occurring. At the same time, in the conditions of the accelerated development of world production, the degree of their harmful effect on NE is growing constantly and with acceleration.

In concurrence with this as experience shows, the degree of harmful effects on NE of different industries of world production is different.

Analysis of the last researches. Long-term, in-depth researches of the current state of NE, which are carring out in the world, show that it has undergone and continues to undergo deep, dangerous, irreversible changes in its state in terms of many indicators of its state, its properties and self-healing capabilities.

The studying of this set of issues shows that, to the greatest regret, now we can talk not about the restoration of the initial (before the creation of world production) NE state, since there is no such possibility, but only about a possible greater slowdown in the degree of the harmful effect of production on it and, consequently, about a possible greater slowdown in the process of deterioration of its condition, the process of its degradation.

The threatening state of the NE and the problem of protecting it from the harmful effects of the developing world production were discussed and highlighted in documents of global importance: in the Kyoto Protocol (1997) and in the Paris Climate Agreement (2015) [2].

In addition, the content of environmental protection has an international energy saving program adopted and implemented by some countries. The role and significance of this program in the problem of protecting the NE is great [3].

An analysis of recent researches shows that in order to get out of the current critical ecological situation, that is, to humanize the attitude of humanity to the NE, it needs to be extremely active in the following directions:

1) the ecologization of production technology and, first of all, energetics, in particular, the creation and expansion of the use of environmentally friendly sources of energy - wind-, solar- and hydro-power, "solar wind" energy, cold nuclear fusion, etc.;

2) expansion of settlements greenery planting, territories of enterprises, roads;

3) strengthening the protection and restoration of lands and forests, in particular, lands draining, protecting them from erosion, planting new forests in areas of felling, etc.;

4) sewage treatment;

5) reducing the volume of storage facilities for household and industrial waste by expanding their utilization;

6) development and improvement of the economic mechanism for NE protecting, in particular by financing the elimination of the consequences of technogenic impact on nature;

7) strengthening of administrative and law counteraction to environmental offenses;

8) harmonization of ecological targeting of population;

9) harmonization of ecological international relations.

It should be noted that in the above series, the first direction is of particular importance, since it reflects the physical, technological substance of each from the multiplicity of industrial objects under study.

However, in the researches conducted, displayed in the available literature, insufficient attention is paid to this direction, especially in relation to the most environmentally aggressive industry - energetics, and in it - to its most environmentally aggressive element - boiler plants.

It is clear, natural and obvious that the uniqueness of the environmental problem under consideration determines the necessity and urgency of using a unique approach and corresponding highly effective means of solving them to solve its particular problems.

In general, it is necessary to abandon the usual ecological predatory strategy of human development. It is necessary to develop, adopt and move on to the rigorous implementation of a

Bulletin of Odessa State Academy of Civil Engineering and Architecture, 2021, no. 85, page 128-136 
global strategy for the ecologically balanced development of humanity. It is necessary to move from the strategy of using the NE to the strategy of parity interaction with it.

Materials and research procedure. World production is represented by a powerful variety of different industries, each of which has reached a certain degree of development. Each production has a certain degree of harmful effect on the NE and a certain set of its types.

The accumulated world experience has established that the most aggressive, dangerous is the multilateral, represented by all branches of physics, the harmful effect of world energetics, its stationary and transport partson on NE $[4,5]$.

This clearly manifests the first law of dialectics: energetics is the most developed, important and useful technical industry for humanity, at the same time it is the most aggressive, dangerous industry in relation to NE, to animate nature, including humanity, and to inanimate nature.

As it's known, modern world energetics includes two parts: the main - stationary one and auxiliary - transport one. In turn, stationary energetics is represented by organic fuel powerproducing units and nuclear fuels power-producing units.

In the current period (and in the foreseeable future), organic fuel energetics is the basic part of the industry's development and will remain its main part in terms of the amount of energy generated.

An increase in fuel consumption leads to an increase in the amount of toxic substances entering the atmosphere during its combustion, 2 times every 12-14 years. The concentration of toxic substances is limited by sanitary standards. For atmospheric air, the maximum one-time and average daily maximum permissible concentration (MPC) of harmful substances in the atmospheric air of settlements is of basic importance. If there is a summation effect, the following relationships must be observed:

$$
\frac{\mathrm{C}_{1}}{\mathrm{MPC}_{1}}+\frac{\mathrm{C}_{2}}{\mathrm{MPC}_{2}}+\ldots+\frac{\mathrm{C}_{\mathrm{n}}}{\mathrm{MPC}_{\mathrm{n}}} \leq 1
$$

where $\mathrm{C} 1, \mathrm{C} 2, \mathrm{Cn}$ is the actual concentration of harmful substances in the atmospheric air; $\mathrm{MPC}_{1}$, $\mathrm{MPC}_{2}, \ldots, \mathrm{MPC}_{\mathrm{n}}$ is maximum permissible concentration of harmful substances in atmospheric air [6].

Also, the air basin is polluted by solid particles entering the atmosphere with the products of fuel combustion at power plants, in industrial and heating boiler houses. About $60 \%$ of the total amount of aerosols released into the air from industrial sources around the world is particulate matter from coal combustion. These are mainly ash and dust. When using low-grade coals, the mineral content increases from the usual $15-30 \%$ to $40-50 \%$.

The annual emission of particles can be determined using the formula:

$$
\mathrm{M}=0,01 \mathrm{~B}\left[\mathrm{a}_{\mathrm{c}} \mathrm{A}^{\mathrm{w}}+\mathrm{q}_{4}^{\mathrm{c}}\left(\mathrm{Q}_{1} / 32680\right)\right]\left(1-\eta_{\mathrm{a}}\right),
$$

where $B$ is the fuel consumption, $t$ /year; $A^{w}$ is ash content per working weight, $\%$; $a_{c}$ is a piece of ash in the carrying away; $\mathrm{q}_{4}{ }^{\mathrm{c}}$ - heat losses from mechanical incompleteness of combustion with carrying away; $\mathrm{Q}_{1}$ is the lowest heat of combustion, $\mathrm{kJ} / \mathrm{kg} ; \eta_{\mathrm{a}}$ is coefficient of efficiency of ash collection [6].

In a number of the main air pollutants - sulfur oxides $\left(\mathrm{SO}_{2}, \mathrm{SO}_{3}\right)$; products of incomplete combustion of fuel: carbon monoxide (CO), aldehydes (mainly $\mathrm{HCHO}$ ), organic acids (acetic $\mathrm{CH}_{3} \mathrm{COOH}$, etc.) and hydrocarbons; carcinogenic substances (primarily 3,4-benzpyrene $\mathrm{C}_{20} \mathrm{H}_{12}$ ), nitrogen oxides $\left(\mathrm{NO}_{\mathrm{x}}\right)$ occupy a special place. The content of nitrogen oxides determines the toxicity of coal combustion products by $40-50 \%$. The gross emission of nitrogen oxides into the air in different regions and cities is $6-8 \%$ of the total emission of all harmful substances, second only to the emission of carbon monoxide, sulfur oxides and particulate matter.

Reducing the formation of nitrogen oxides in boilers can be achieved by reducing the maximum local temperature in the flare by ballasting the blast air with flue gases, water or steam, as well as two-stage fuel combustion.

A decrease in the formation of nitrogen oxides in the designed boilers can be ensured by a decrease in the maximum temperature and a decrease in the time of $\mathrm{NO}_{\mathrm{x}}$ formation in addition to the following methods: dividing the combustion chamber into sections by two-light screens, using volume-cooled furnaces; dispersion of the combustion front, etc. [7].

In the future way of reducing the harmful effect of world production on NE it should be established by law lower accepted level of the maximum concentration of gaseous and solid 
harmful substances in the atmospheric air.

The intense harmful impact of the energetics on NE is complex and very multifaceted. In general, protection from this impact is an extremely complex and important in all respects environmental problem of the present and the future.

The impact of the energetics as a whole significantly exceeds in intensity the total impact on $\mathrm{NE}$ of all other sectors of the present world production. It has a versatile, complex, systemic nature, negatively affects the course and results of the natural processes of the functioning of NE objects.

According to the current assessment, humanity, on the way of its development and exerting a harmful effect on NE from the production created by it, has passed the point of no return to its prosperous state. As a result, there was only an opportunity to slow down and then stop the increase in the harmful effect on it. The realization of this opportunity is the substance of the nature conservation activities of humanity now and in the future.

Research results. The power-producing units used today are a complex set of equipment. Among their elements, the most intense and multifaceted harmful effect on NE is exerted by boiler plants (BP), especially those operating on solid fuels [8].

Other industry objects using fire - furnaces, dryers - also negatively affect NE, but their number is negligible in comparison with the number of BP units in their world fleet.

The harmful impact of BP on NE is complex, multifaceted, large-scale and manifests itself in the following:

- emission and discharge of heat into NE;

- greenhouse gas emissions;

- emission of harmful, poisonous gases;

- emission of finely-divided particles of ash and carbon (soot);

- discharge of chemically contaminated water;

- pollution of the atmosphere around the boiler house with dust particles of fuel and ash, during their processing in coal and ash slag storage;

- abruption of the area for the placement of the boiler house infrastructure;

- abruption of the area for the placement of elements of railway tracks and highways, heat and current networks;

- landscape damagewith a high smoke stack and electricity pylons;

- acoustic impact on the ambient space - noise.

Among the listed impacts on NE, the most aggressive are emission and discharge of heat and toxic substances into NE. Reducing the intensity of their impact is the main area of activity for the protection of NE.

Among modern technical objects, the technical community considers the power generating unit (boiler - turbine - generator) of a large thermal power plant to be the most difficult. The most difficult part of it is BP. Its most complex element is a high-pressure steam boiler that burns solid fuel [9].

Such a power generating unit usually operates in a tense mode: it carries a load that often and rapidly changes in level.

Solid fuel boilers, especially those that have undergone significant wear and tear, pollute NE with heat and fly ash.

The level of environmental friendliness of the boiler depends significantly on the degree of its wear. In Ukraine, the fleet of operating boilers consists of units, most of which have worked out their resource. Under these conditions, the fleet of boilers renewing problem is the question of the hour [10].

In Ukraine, boiler industry as an important and responsible part of the domestic engineering industry, needs intensive development. A special place here is occupied by the task of organizing an expanded and complete renewal of the fleet of operating boilers, especially of small and medium power.

It should be noted that an important circumstance is that the task of a modern power generating unit control, especially its BP control, is very difficult and responsible. At the same time, from automatic control system of BP of the power generating unit they demand high control quality.

All this gives to task of control of the level of ecological efficiency of the boiler and the BP a features of a high degree of complexity and responsibility.

Bulletin of Odessa State Academy of Civil Engineering and Architecture, 2021, no. 85, page 128-136 
Against the background of the foregoing, the features and complexity of control of the solution of the problem of reducing the harmful impact of the BP park and the energetics as a whole on NE become clearer.

Thus, in order to solve the problem of NE protecting from the harmful effects of power generating plants, it is necessary reliably, high-quality to control the technological efficiency of their functioning, first of all, to control of its ecological component.

The solution of this problem is reduced, in essence, to the problem of high-quality control of the level of ecological efficiency of the functioning of the most aggressive elements of power generating plants $-\mathrm{BP}$.

At the beginning of 2019, in the world of natural surroundings, burdened by the harmful effects of production, a major climatic anomaly broke out which still carries catastrophic consequences. A significant part of the responsibility for these consequences lies with the world production, and in it, first of all, with the existing BP fleet.

The above material shows that in solving the NE protecting problem from the harmful effects of world production, energetics should be used as a means of its environmental friendliness control. It also shows that in the energetics, in order to solve this epoch-making problem in terms of importance, the BP park should be used as a tool for control of energetics environmental friendliness.

Taking into account the foregoing, the general line of the environmental friendliness of world production improving should be considered the use of all available ways and means of increasing of the environmental efficiency of the functioning of operating fossil fuel power plants level, first of all, reducing their emission of carbon dioxide and heat.

It is necessary to decisively improve BP thermal scheme, its design, technological process, to raise the technological efficiency of functioning level, to improve the control quality of working process of the operating BP.

It is important to ensure the modernization of worn out BP, on the basis of carrying out a complete renewal of those of their number that have used up their resource, and carrying out a partial renewal of those that are on the trajectory of expenditure of their estimated service life [10].

It is necessary and expedient to implement a program for the modernization of boilers in the BP world park, with the active participation in it and creative interaction of specialists from the countries of the world community.

In Ukraine, proper attention is paid to the problem of normalizing the ecological situation, to the attitude of society towards the NE at the legislative level.

The development of the state, society and production is focused on strict observance of legislatively established norms and rules of an environmental nature $[11,12]$.

A set of important legislative acts of environmental protection has been adopted and is being implemented [13].

The problem of the ecological situation normalizing has become high relevant in the southern region, in particular, in the Odessa region, taking into account the specific environmental threats: pollution of the Black Sea by sewage, deterioration of the quality of air, drinking water, accumulation of solid waste, uncontrolled use of GMOs, the problem of water resources in the Kuyalnik estuary, the Grand Kuyalnik river, its tributaries and etc. Climate change affects the Odessa region in the form droughts, gusty winds, tropical downpours, sea bloom, etc. Ineffective treatment of industrial and domestic wastewater in the rivers of Ukraine, which flow to the south and carry pollutants into the Black Sea, creates its eutrophication and contributes to its bacterial and chemical pollution.

The destruction of natural ecosystems in the Odessa region is facilitated by the large-scale development of the sea coast. Construction on slopes is fraught with collapses along the entire coastline. The risk of landslides is also extensive due to the outdated fortification systems built in the 1960-1980s. Anthropogenic pressure on coastal areas and water areas in the region is enormous. Also, old sewerage systems lead to the accumulation of wastewater in the sea, which leads to its pollution. In summer, this causes outbreaks of toxic blue-green algae growth.

In the region, there was a serious situation with land resources, which needed to be made national natural parks, but in recent years, the prairie areas and gulches of the region have become farmland. 
A negative contribution to the state of the Odessa region ecosystem is made by matters of uncontrolled tourism and land privatization in protected areas, the dangers and harmfulness of nuclear energy and energy production from fossil fuels, non-compliance with international rules and safety standards for oil transportation through the Black Sea and the development of oil infrastructure.

Climate change affects the Odessa region in the form of drought, gusty winds, tropical showers, sea blooms, etc. This leads to the impoverishment of natural resources in the region, especially fresh water, and can lead to irreversible degradation of the environment, migration of the population, if immediate and concerted action is not taken.

All this motivates civic initiative. Thus, it is planned to create a public ecological center "Odessa Eco-House" in the Odessa city. The Odessa Municipal Center for Environmental Safety is making successful steps.

The efforts made in the Odessa region to improve the level of environmental friendliness of power generating plants, especially BP, through partial renewal are very relevant. The operation of obsolete BP leads to soil pollution, water bodies and groundwater, as well as the ingress of hydrocarbon combustion products into the atmosphere. Modernization of the energy sector of the Odessa region can play an important role in the modernization of the entire economy of southern Ukraine.

The exceptional importance of the problem of immediate, radical change - humanization - of the attitude of humanity to the NE is obvious. We need broad, comprehensive, decisive action in all spheres of society and branches of industry. They should reflect a new concept, a new position of humanity in relation to the NE, element by element. In the energetics the novelty of the attitude to the NE should be manifested most widely and fully.

There is reason to believe that it is advisable to develop a general program for the modernization of the BP global park according to enlarged indicators and the development of particular programs for each state, each of which will reflect the local features of the use of the existing BP national park.

It is clear, natural and obvious that the uniqueness of the problem has led to the need and urgency of using, for the implementation of its tasks, an extraordinary approach and the corresponding highly effective methods and means of solving them in the shortest possible period of time.

As the analysis of the available information on the ecological situation on Earth shows, especially in the period of the XVIII-XX centuries, under the harmful influence of rapidly developing production, the process of deterioration of the state of the NE occurs, and it occurs with an acceleration.

Therefore, in order to suspend the process of deterioration of the NE state, it is necessary to reduce the intensity of the harmful effect of production on it to the level of the speed of the process of improving its state, due to the natural process of self-healing of NE objects.

The cardinal, fundamental importance of this condition in the sphere of human interaction with the NE is obvious.

In this regard, the problem of normalizing the global environmental situation facing humanity forces it to take a set of impacts on world production that can reliably and sustainably reduce the intensity of its harmful impact on NE.

Ukraine has a powerful, modern, well-developed industrial base. The energy industry, modern in terms of the nature of the equipment used, bears a load that generally meets the needs of the state and society.

At the same time, the domestic energetics in fact functions in extremely difficult conditions.

The process of timely provision of consumers with solid, liquid, gaseous fuels takes place in the mode of overcoming significant difficulties of various kinds.

The boiler park, numbering more than 60 thousand units, more than $95 \%$ consists of units that have worked out more than $1,5-2,5$ working resources.

These boilers, being heavily worn out, operate with low technological efficiency and, naturally, with low environmental friendliness.

This fleet of boilers has a significant harmful effect on the NE.

The set of measures to be carried out in the process of solving a problem forms a mechanism for solving its tasks.

At the beginning of work on a problem, its mechanism is activated and the process of this

Bulletin of Odessa State Academy of Civil Engineering and Architecture, 2021, no. 85, page 128-136 
mechanism control is turned on.

As it known, the quality of control process affects the level of its efficiency.

The quality of control of mechanism for solving the world problem will have a direct impact on the quality of this solution, on its efficiency.

\section{Conclusions:}

1. The developing world production has a harmful effect on NE, the level of which has become intolerable for it. The problem of normalizing the interaction of humanity and NE arose.

2. An obligatory effect of the production process is its harmful effect on NE, carried out by a certain residual waste product of the technological process and a certain energy effect of this process.

3. Secondary effects, harmful to NE, accumulate in NE, and in the conditions of accelerated development of world production, the degree of their harmful effect on NE is continuously and rapidly increasing.

4. To get out of the current critical environmental situation, that is, to humanize the attitude of mankind to NE, it needs to be extremely active in several directions, the main of which is the greening of production technology and, above all, energetics.

5. Among the branches of world production, the most harmful effect on NE is exerted by energetics, especially its stationary part, which uses organic fuel.

6. Among the elements of stationary energetics on organic fuel, the most severe harmful effect on NE is exerted by BP.

7. Among the components of BP harmful effect on NE the most aggressive is the emission of greenhouse gases and heat.

8. The strongest harmful effect on NE is exerted by BP on solid fuel.

9. The level of boiler environmental friendliness depends significantly on the degree of its wear.

10. In Ukraine, the fleet of operating boilers consists of units, most of which have worked out their resource, therefore the problem of renewal the fleet of boilers is extremely actual.

11. In the catastrophic consequences of the climatic anomaly in 2019, a significant share of responsibility lies with the energy industry, the global park of BP.

12. Humanity is faced with an extremely complex global problem of urgently taking a set of measures aimed at normalizing the interaction of humanity, its world production with NE.

13. At present, there is only an opportunity to slow down and then stop the increase in the harmful effect of production on NE, the implementation of which is the essence of the nature conservation activities of humanity today and in the future.

14. The problem of decisive improvement of the heat diagram, technological process, design, increasing the environmental friendliness of BP, improving the quality of control of the process of their functioning arose.

15. To make the efforts of humanity to reduce the harmful effects of BP used in the world on $\mathrm{NE}$ effective, an international, comprehensive program of their deep modernization with the participation of specialists from all countries is needed.

16. The modernization program of the existing global fleet of BP should contain the concept of a proper increase in their environmental efficiency to an acceptable, affordable high level in the near perspective.

17. Anthropogenic and natural destruction of natural ecosystems and the problem of normalizing the ecological situation has become highly relevant in the southern region, in particular, in the Odessa region, taking into account specific environmental threats.

18. Modernization of the energy sector of the Odessa region can play a decisive role in the modernization of the entire south of Ukraine.

\section{References}

[1] B.I. Basok, E.T. Bazeev, "Energetichna strategiya v realiyah suchasnogo svitu (oglyad)", Teplofizika ta teploenergetika, vol. 41, no. 1, pp. $34-42,2019$.

[2] I.M. Kirpach, "Upravlinnya prirodokoristuvannyam na shlyahu do ekologobezpechnogo rozvitku", Bulletin of the National University of Water and Environmental Engineering, Issue 2(26), Part 2, pp. 493 - 499, 2004. 
[3] O.P. Voinov, Yu.G. Elkin, "About the significance of energy saving program. Ecological aspect", Bulleten of the Odessa State Academy of Civil Engineering and Architecture, Issue 76, pp. 119 - 125, 2019.

[4] P. Omelyanovskiy, J. Mysak, Teplova energetika - novi vikliki chasu. Lviv: NVF Ukrayinski tehnologiyi, 2009.

[5] A. Voinov, Yu. El'kin, S. Kryukovskaya-Telezhenko, "Vozdejstvie na ekologicheskuyu effektivnost' energetiki - sredstvo upravleniya ekologichnost'yu mirovogo proizvodstva", Ekologiya i vodnoe hozyajstvo (Baku), no. 1, pp. 6-9, 2020.

[6] I.Ya. Sigal, Zashchita vozdushnogo bassejna pri szhiganii topliva. Leningrad: Nedra, 1988.

[7] A.P. Voinov, S.A. Voinova, "Osobennosti upravleniya tekhnologicheskim processom v obyomno-ohlazhdaemyh topkah kotlov", Budivnictvo ta tekhnogenna bezpeka. Simferopol': Nacional'na akademiya prirodoohoronnogo i kurortnogo budivnictva. Issue. 51, pp. $105-109,2014$.

[8] A.P. Voinov, S.A. Voinova, "Upravlenie ekologichnost'yu kotlov - prioritetnaya zadacha razvitiya kotlostroeniya v Ukraine", Avtomatizaciya tekhnologichnih i biznes-procesiv, no. 9,10 , pp. $25-29,2012$.

[9] A.P. Voinov, "Razvitie kotlostroeniya - ostraya problema razvitiya mashinostroeniya $\mathrm{v}$ Ukraine", Energetika ta elektrifikaciya, no. 5, pp. 5- 8, 2016.

[10] S.A. Voinova, A.P. Voinov, "Obnovlenie - vysokoproduktivnyj metod povysheniya urovnya effektivnosti funkcionirovaniya ob'ektov proizvodstva", Energetika ta elektrifikaciya, no. 7, pp. 33 - 36, 2017.

[11] O.V. Kratko, L.Ya. Muntyan, L.I. Demchuk, "Ekologichna bezpeka Ukrayini v konteksti stalogo rozvitku", Ekologichni nauki, Issue 1(34), pp. 219 - 224, 2021.

[12] Yu.M. Matsevitiy, A.V. Rusanov, V.A. Solovey, A.A. Tarelin, "Zabezpechennya rozvitku ekologichnoyi energetiki visokoyi efektivnosti", Problemyi ekologii i ekspluatatsii ob'ektov energetiki. Institut problem ekologii. Kiyiv.: IPTs AKON NAN Ukrayini, pp. 31 - 36, 2017.

[13] Zakon Ukrayini «Pro Osnovni zasadi (strategiyu) derzhavnoyi ekologichnoyi politiki Ukrayini na period do 2030 roku». No. 2697-VIII vid 28 lyutogo 2019r. [Online]. Available: https://zakon.rada.gov.ua/laws/show/2697-19\#Text. Accessed on: September 08, 2021.

\title{
КОТЕЛЬНІ УСТАНОВКИ ТА ЗАХИСТ ПРИРОДНОГО СЕРЕДОВИЩА ВІД ШКІДЛИВОГО ВПЛИВУ ВИРОБНИЦТВА
}

\author{
${ }^{1}$ Воінов О.П., д.т.н., професор, \\ voinova_s@yahoo.com, ORCID: 0000-0001-7548-4212 \\ ${ }^{1}$ Елькін Ю.Г., к.Т.Н., доцент, \\ yrik29@gmail.com, ORCID: 0000-0001-7677-377X \\ ${ }^{1}$ Одеська державна академія будівниитва і архітектури \\ вул. Дідріхсона, 4, м. Одеса, 65029, Україна
}

\begin{abstract}
Анотація. В даний час загострилася екологічна проблематика. Виробничий процес негативно впливає на природне середовище. У ній накопичуються ці шкідливі для неї вторинні ефекти. Ступінь їх шкідливого впливу прискорено зростає. Природне середовище, 3 урахуванням іiі самовідновлення, зазнає небезпечних, незворотні зміни свого стану. Нині можливо вести мову лише про уповільнення цього процесу. Можливість уповільнити, а потім зупинити підвищення шкідливого впливу на природне середовище становить суть природоохоронної діяльності людства. Необхідно перейти від стратегії використання природного середовища до стратегії паритетної взаємодії з нею. Проблема обговорювалася на Кіотській i Паризькій нарадах світового значення. Серед галузей виробництва найбільш небезпечною для природного середовища $\epsilon$ енергетика. Її шкідливий вплив має комплексний характер. Захист від нього $\epsilon$ складною екологічною проблемою. Прийнята програма енергозбереження активно сприяє вирішенню проблеми порятунку природного середовища від деградації і загибелі. Найбільш екологічно агресивним елементом енергоустановок $\epsilon$ котельні установки, що працюють на твердому паливі. Скорочення інтенсивності їх впливу є основним
\end{abstract}

Bulletin of Odessa State Academy of Civil Engineering and Architecture, 2021, no. 85, page 128-136 
напрямком діяльності щодо захисту природного середовища. Найскладнішим технічним об'єктом вважається енергоблок великої теплової електростанції. Найскладнішою його частиною $\epsilon$ котельня установка. Найскладнішим її елементом $є$ паровий котел. Рівень екологічності котла сильно залежить від ступеня його зносу. Проблема оновлення парку котлів має актуальне значення. Генеральною лінією підвищення екологічності виробництва слід вважати підвищення рівня екологічності енергоустановок, особливо на органічному паливі, зменшення емісії ними вуглекислого газу і теплоти. Необхідно вдосконалювати котельні установки, підвищувати рівень ïx ефективності, якість управління ними. Важливо забезпечити модернізацію зношених котельних установок на основі повного або часткового їхнього відновлення. У становленні енергетики майбутнього соціально-психологічна позиція людства повинна докорінно змінитися.

Ключові слова: природне середовище, світове виробництво, енергетика, котельна установка, шкідливий вплив, екологічність.

\title{
КОТЕЛЬНЫЕ УСТАНОВКИ И ЗАЩИТА ПРИРОДНОЙ СРЕДЫ ОТ ВРЕДНОГО ВОЗДЕЙСТВИЯ ПРОИЗВОДСТВА
}

\author{
${ }^{1}$ Воинов А.П., Д.т.н., профессор, \\ voinova_s@yahoo.com, ORCID: 0000-0001-7548-4212 \\ ${ }^{1}$ Элькин Ю.Г., к.т.н., доцент, \\ yrik29@gmail.com, ORCID: 0000-0001-7677-377X \\ ${ }^{1}$ Одесская государственная академия строительства и архитектуры, \\ ул. Дидрихсона, 4, г. Одесса, 65029, Украина
}

\begin{abstract}
Аннотация. В настоящее время обострилась экологическая проблематика. Производственный процесс отрицательно влияет на природную среду. В ней скапливаются эти вредные для нее вторичные эффекты. Степень их вредного воздействия ускоренно растет. Естественная среда, с учетом ее самовосстановления, претерпевает опасные, необратимые изменения своего состояния. В настоящее время можно говорить только о замедлении этого процесса. Возможность замедлить, а затем остановить повышение вредного воздействия на природную среду составляет существо природоохранной деятельности человечества. Необходимо перейти от стратегии использования природной среды к стратегии паритетного взаимодействия с ней. Проблема обсуждалась на Киотском и Парижском совещаниях мирового значения. Среди отраслей производства наиболее опасной для природной среды является энергетика. Ее вредное влияние носит комплексный характер. Защита от него является сложной экологической проблемой. Принятая программа энергосбережения активно способствует решению проблемы спасения природной среды от деградации и гибели. Наиболее экологически агрессивным элементом энергоустановок являются котельные установки, работающие на твердом топливе. Сокращение интенсивности их влияния является основным направлением деятельности по защите природной среды. Самым сложным техническим объектом считается энергоблок большой тепловой электростанции. Самой сложной его частью является котельная установка. Самым ее сложным элементом является паровой котел. Уровень экологичности котла сильно зависит от степени его износа. Проблема обновления парка котлов имеет актуальное значение. Генеральной линией повышения экологичности производства следует считать повышение уровня экологичности энергоустановок, особенно на органическом топливе, уменьшение эмиссии ими углекислого газа и теплоты. Необходимо усовершенствовать котельные установки, повышать уровень их эффективности, качество управления ими. Важно обеспечить модернизацию изношенных котельных установок на основе полного или частичного обновления. В становлении энергетики грядущего социальнопсихологическая позиция человечества обязана коренным образом поменяться.
\end{abstract}

Ключевые слова: природная среда, мировое производство, энергетика, котельная установка, вредное воздействие, экологичность.

Стаття надійшла до редакції 10.09.2021

136 Bulletin of Odessa State Academy of Civil Engineering and Architecture, 2021, no. 85, page 128-136 